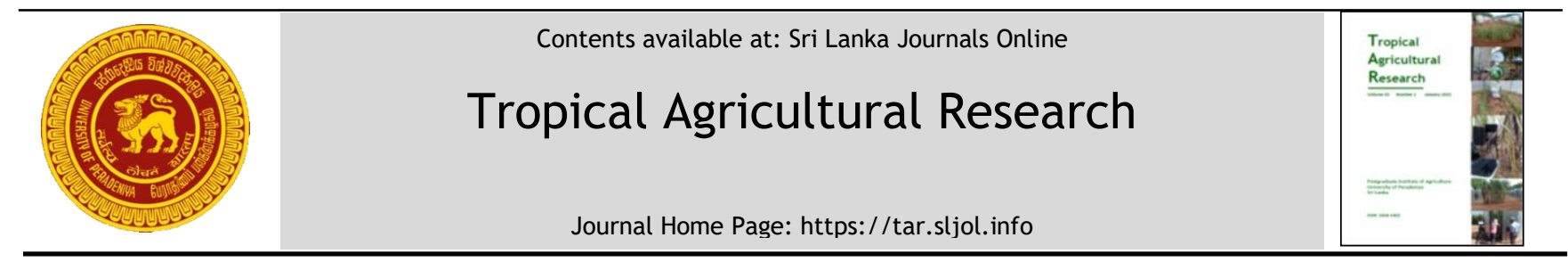

\title{
Snap Bean Breeding for Rust Resistance: Validation of Molecular Markers for The Ur-11 Gene Introgression
}

\author{
H.M.P.S. Kumari ${ }^{*}$, C.K. Weebadde², P.C.G. Bandaranayake³ ${ }^{3}$ M. A. Pastor Corrales ${ }^{4}$, R.G.A.S. Rajapakshe ${ }^{1}$ \\ ${ }^{1}$ Horticultural Crops Research and Development Institute, Gannoruwa, Sri Lanka \\ 2 Plant Soil and Microbial Sciences, Michigan State University, East Lansing, MI, USA \\ ${ }^{3}$ Agricultural Biotechnology Centre, University of Peradeniya, Sri Lanka \\ ${ }^{4}$ United States Department of Agriculture-Agricultural Research Service, Soybean Genomics and Improvement Laboratory, \\ Beltsville, Agricultural Research Center, Beltsville, Maryland, USA
}

\section{ARTICLE INFO}

\section{Article history:}

Received: 11 July 2021

Revised version received: 30 September 2021

Accepted: 11 October 2021

Available online: 01 January 2022

\section{Keywords:}

Inheritance of resistance

Marker-assisted breeding

Single gene inheritance

Uromyces appendiculatus

\section{Citation:}

Kumari, H.M.P.S., Weebadde, C.K., Bandaranayake, P.C.G., Corrales Pastor, M.A. and Rajapakshe, R.G.A.S. (2022). Snap bean breeding for rust resistance: validation of molecular markers for the Ur-11 gene introgression. Tropical Agricultural Research, 33(1): 57-66.

DOI: http://doi.org/10.4038/tar.v33i1.8535

Kumari, H.M.P.S. (iD

https://orcid.org/0000-0002-5935-9646

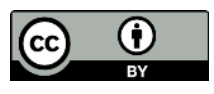

\section{ABSTRACT}

Bean rust caused by Uromyces appendiculatus_fungus is one of the most destructive diseases reported in temperate, tropical, and sub-tropical regions, affecting the quality and quantity of common bean (Phaseolus vulgaris $L$ ) yield. The present study aimed to improve the breeding process of snap beans for rust resistance by identification of inheritance patterns of resistant genes using phenotypic and molecular markers. Among the different genes identified, Ur-11 has wide-spectrum resistance to 89 out of 90 reported races of the rust pathogen. Therefore, the common bean cultivar PI 181996, having the Ur11 gene was used as the rust resistance donor parent while the local popular snap bean variety Kappetipola nil, susceptible to all locally reported races of the rust pathogen in Sri Lanka, was selected as the susceptible (Recurrent) parent. The introgression of the Ur-11 gene from the cultivar PI 181996 in $\mathrm{F}_{1}, \mathrm{~F}_{2}$, and $\mathrm{BC}_{1} \mathrm{~F}_{1}$ populations were phenotypically evaluated using standard screening method while validating random amplified polymorphic DNA (RAPD) marker, OPAC 20 and sequence characterized amplified region (SCAR) marker, SAE 19 and GT 2. Coupling markers (OPAC 20 and GT-2) and repulsion marker (SAE 19) showed $95 \%$ and $100 \%$ of expected results for phenotypically resistant and susceptible lines respectively. The results showed that the Ur-11 gene in PI 181996 can be tagged with SCAR marker GT-2 and SAE 19 and can be used for markerassisted selection to identify the presence of the Ur-11 gene in the snap bean rust-resistance breeding program. Introgression of the Ur-11 gene helped to develop genetic resistance to local races of the rust pathogen, and the selected progenies could be developed as new resistant snap bean breeding lines

\footnotetext{
*Corresponding author: pabakumari68@yahoo.com
} 


\section{INTRODUCTION}

The common bean (Phaseolus vulgaris L.) is cultivated primarily as dry and snap beans, consumes mainly as mature seeds of dry beans and immature green pods of snap beans, respectively. The Snap bean is a high-value vegetable crop in Sri Lanka with high nutritional value (Broughton et al., 2003; Hangen \& Bennink, 2003). Pests and pathogens are among the leading causes of yield and quality losses of common bean cultivation worldwide (Kakolongo, 2018). Among many common bean diseases, bean rust, caused by the basidiomycete fungus Uromyces appendiculatus (Pers), is the most destructive disease. For example, an increase of $1 \%$ disease severity in bean rust leads to a yield loss of approximately $19 \mathrm{~kg} / \mathrm{ha}$ (Souza et al., 2014).

Resistance breeding is considered the most costeffective disease management strategy (Stavely, 2000; Souza et al., 2014). Based on the evidence, single dominant genes control the rust resistance (RR) of the common bean, and 10 of these RR genes (Ur-3, Ur-4, Ur-5, Ur-6, Ur-7, Ur-9, Ur-11, Ur-12,Ur-13, and $U r-14$ ) have so far been identified, named and mapped (Hurtado-Gonzales et al., 2017). Conversely, the virulence pattern of $U$. appendiculatus is unique to different countries and requires the use of specific resistant genes in breeding bean cultivars with resistance to rust (Araya et al., 2004; Liebenberg et al., 2003; Souza et al., 2007; Acevedo et al., 2008; Alleyne et al., 2008). The $U r-11$ RR gene found in chromosome 11 has shown resistance to 89 out of 90 known rust races worldwide (Pastor Corrales, 2001). The Middle American common bean accession PI 181996 carries the $U r-11$ gene that has been utilized as a donor parent to the introgression of a wide range of resistance in bean breeding(Souza et al., 2014).

Phenotypic screening is challenging in selecting genotypes with RR genes, as it requires serial inoculations of the same plant or population (Pastor Corrales, 2001). This limitation affects the accuracy and efficiency of the selection process and breeding (Souza et al., 2007). The use of molecular markers linked to the resistance genes would address such limitations (Hurtado-Gonzales et al., 2017). The random amplified polymorphic DNAs (RAPDs) and sequence characterized amplified region (SCAR) markers have previously been used in marker-assisted breeding and for pyramiding resistant genes in bean breeding (Miklas et al., 2006). The RAPD marker OAC 20490 and OAE 19890 and SCAR markers SAE19 and UR 11-GT2 have previously been used for confirmation of the introgression ofthe Ur-11 gene(Miklas etal.,2002;
Kelly et al., 2003; Miklas et al., 2006). Further, the RAPD marker OAC20490 and SCAR marker Ur-11GT2 use as coupling phase markers, and RAPD marker OAE19890 and SCAR marker SAE 19 are used as repulsion phase markers to identify segregating populations with introgression of the Ur-11 gene present in PI 181996 (Miklas et al., 2006).

The use of resistant cultivars to develop rustresistant snap bean varieties is important for the integrated management of the rust disease of snap beans in Sri Lanka. Currently, there are no recommended rust-resistant snap bean varieties in the country (Ariyarathne et al., 2001). Using broadspectrum resistant genes from resistant sources is a key strategy for developing durable resistance against many $U$. appendiculatus races. We recently identified four different predominant races of the rust pathogen: 63-21, 23-5, 31-1, and 31-11 in Sri Lanka (Publication pending). Pastor Corrales (2001) reported that the differential cultivar PI 181996 with the U-11 gene was resistant to all four races (Pastor Corrales, 2001). A series of tightly linked dominant genes control the rust resistance of PI 181996 (Stavely, 2000; Souza et al., 2014 Hurtado-Gonzales et al., 2017).

In this study, we initiated the pyramiding of resistant genes by incorporating the $U r-11$ gene from PI 181996 into the locally popular snap bean variety, Kappetipola nil. We also used the previously developed RAPD and SCAR markers to identify and differentiate resistant and susceptible progenies in the F1, F2 and backcrossed (BC1F1) populations. This study includes validation of DNA markers useful for the marker-assisted breeding techniques to improve the efficiency of conventional breeding methods for developing rust-resistantvarieties of snap beans in Sri Lanka.

\section{METHODOLOGY}

\section{Plant Materials and Development of Breeding Populations}

Popular snap bean variety Kappetipola nil was used as the recurrent susceptible female parent (P1) in this study. This variety is one of the most popular pole snap bean varieties cultivated in Sri Lanka with the farmer and consumer-preferred pod characters. Nevertheless, it is considered as one of the most susceptible to the local races of the bean rust pathogen (Ariyarathne etal., 2001). The Middle American common bean accession (Guatemalan black bean) plant introduction (PI) 181996 was used as the rust-resistant donor parent $\left(\mathrm{P}_{2}\right)$ to incorporate the $U r$ - 11 gene. 
The United States Department of Agriculture (USDA), Maryland, Beltville, USA, provided PI 181996 germplasm. Ten $\mathrm{F}_{1}$ resistant plants obtained from the Kappetipola nil x PI 181996 cross combination gave rise to the $F_{2}$ population. The back-crossed generation was created using Kappetipola nil as the recurrent parent and PI 181996 as the donor parent. All the $F_{1}, F_{2}$, and $\mathrm{BC}_{1} \mathrm{~F}_{1}$ plants were inoculated with locally identified rust pathogen races. The rust screening trials were conducted in greenhouse conditions at the Horticultural Crops Research and Development Institute, Gannoruwa, Sri Lanka (GPS $7.8731^{\circ} \mathrm{N}$, $\left.80.7718{ }^{\circ} \mathrm{E}\right)$. The Chi- square statistics were generated using Pearson's chi-square test and utilized for hypothesis testing of the inheritance of the rust resistance trait. A spore suspension from each of the predominant and four identified races of rust pathogens (63-21, 23-5, 31-1, and 31-11) was used for the disease screening trial.

\section{Phenotypic Scoring for Virulence}

The reaction of common bean cultivars to races of the rust pathogen was determined using the scale adopted at the 1983 Bean Rust Workshop and modified by Steadman et al. (2002). This scale consists of six reaction grades based on distinct phenotypes (Table 1).

While the cultivars that presented the grades 3 or lower were classified as resistant, those with grades 4 or higher were considered susceptible. When several reaction types were present, they were recorded in the order of predominance, the most prevalent listed first and the least prevalent listed the last (Pastor Corrales, 2002).

Table 1. Standard bean rust grading scale for rating the reaction of bean plants to the rust pathogen (Uromyces appendiculatus)

\begin{tabular}{|c|c|c|c|}
\hline \multirow{2}{*}{$\begin{array}{l}\text { Reaction } \\
\text { Grade } \\
\mathbf{1}\end{array}$} & \multirow[b]{2}{*}{$\begin{array}{llll}\text { Immune, having } & \text { no visible } \\
\text { symptoms }\end{array}$} & \multicolumn{2}{|c|}{ Symbols, and their definition } \\
\hline & & I & Immune \\
\hline 2 & $\begin{array}{l}\text { Necrotic or chlorotic spots without } \\
\text { sporulation, and less than } 0.3 \mathrm{~mm} \text { in } \\
\text { diameter }\end{array}$ & HR & $\begin{array}{l}\text { Hypersensitive reaction; considered } \\
\text { resistant }\end{array}$ \\
\hline $2+$ & $\begin{array}{l}\text { Necrotic spots, without sporulation, 0.3- } \\
1.0 \mathrm{~mm} \text { diameter }\end{array}$ & HR & Hypersensitive reaction, Resistant \\
\hline $2++$ & $\begin{array}{l}\text { Necrotic spots without sporulation, } \\
1.0-3.0 \mathrm{~mm} \text { diameter }\end{array}$ & HR & Hypersensitive Reaction, Resistant \\
\hline $2+++$ & $\begin{array}{l}\text { Necrotic spots without sporulation, } \\
\text { greater than } 3.0 \mathrm{~mm} \text { diameter }\end{array}$ & HR & Hypersensitive Reaction, Resistant \\
\hline 3 & $\begin{array}{l}\text { Small, tiny sporulating pustules } \\
\text { (uredinia) less than } 0.3 \mathrm{~mm} \\
\text { diameter }\end{array}$ & $\mathbf{R}$ & $\begin{array}{l}\text { Resistant: Grade } 3 \text { present or } \\
\text { predominant - Having any of the } \\
\text { grades } 2 \text { with some grade } 4\end{array}$ \\
\hline 4 & $\begin{array}{l}\text { Uredinia (Sporulating pustules) } 0.3 \\
-0.5 \mathrm{~mm} \text { diameter and not larger than } \\
0.5 \mathrm{~mm}\end{array}$ & MS & $\begin{array}{l}\text { Moderately Susceptible Grade } 4 \\
\text { predominant and no grade } 5 \\
\text { uredinia }\end{array}$ \\
\hline 5 & $\begin{array}{l}\text { Uredinia (Sporulating pustules) } 0.5 \\
-0.8 \mathrm{~mm} \text { diameter but not larger } \\
\text { than } 0.8 \mathrm{~mm}\end{array}$ & $S$ & $\begin{array}{l}\text { Susceptible Uredinia larger than } \\
\text { grade } 4 \text {, but none larger than } \\
\text { grade } 5\end{array}$ \\
\hline $6 \quad y^{4}$ & $\begin{array}{l}\text { Uredinia (Sporulating pustules) } \\
\text { larger than } 0.8 \mathrm{~mm} \text { diameter }\end{array}$ & $\begin{array}{ll}S & \text { and } \\
\text { VS } & \end{array}$ & VerySusceptible.Grade6uredia \\
\hline
\end{tabular}

Steadman et al. 2002 


\section{Preparation of Rust Spore Suspension}

Four locally identified races of $U$. appendiculatus $(63-21,23-5,31-11,31-1)$ were used in the inoculation procedure. Approximately $0.03 \mathrm{~g}$ of a frozen uredinium spore sample was dissolved in $250 \mathrm{ml}$ of tap water containing $0.01 \%$ Tween -20 . It was mixed using a magnetic stirrer at about $800 \mathrm{rpm}$ speed to obtain a uniformly dispersed spore sample. The spore concentration was determined using a hemocytometer and was adjusted to a spore concentration of $2 \times 10^{4}$ uredospores per $\mathrm{ml}$.

\section{Rust Virulent Test Plant Preparation and Inoculation for F1, F2 and BC1F1 Plants}

Identified plants for the virulence test were planted in pots containing a 1:1:1 mixture of surface soil, sand, and compost. Ten days after planting, primary leaves of the snap bean plants were inoculated with selected rust spores according to the method described by Pastor Corrales, 2002 (Figure 1). Isolates of the rust pathogens were separately suspended in Tween-20 (0.01 v/v) dissolved in $250 \mathrm{ml}$ of tap water, as described above. The inoculum suspension was then sprayed onto the abaxial surface of the bean leaves (Figure 1b). After inoculation, the plants were kept in a moistchamber $\left(20 \pm 10{ }^{\circ} \mathrm{C}\right.$ and relative humidity 80 $95 \%$ ) for $18 \mathrm{hrs}$ under darkness (Figure 1c). To avoid contaminations, plants inoculated with each isolate were kept separated in the mist chamber. After the incubation period, plants were transferred to the greenhouse $\left(25 \pm 5{ }^{\circ} \mathrm{C}\right.$ and relative humidity $80-95 \%$ ), where they were kept until the evaluation of symptoms. Visible rust symptoms were observed and scored 10 - 12 days after inoculation and plants were visually evaluated based on the standard scale of six reaction degrees (Pastor Corrales, 2001). Microscopic observations and measurements were taken for tiny pustules to ensure the length and width of the pustule to evaluate a resistant or susceptible reaction with the recommended grading scale (Table 1 ).
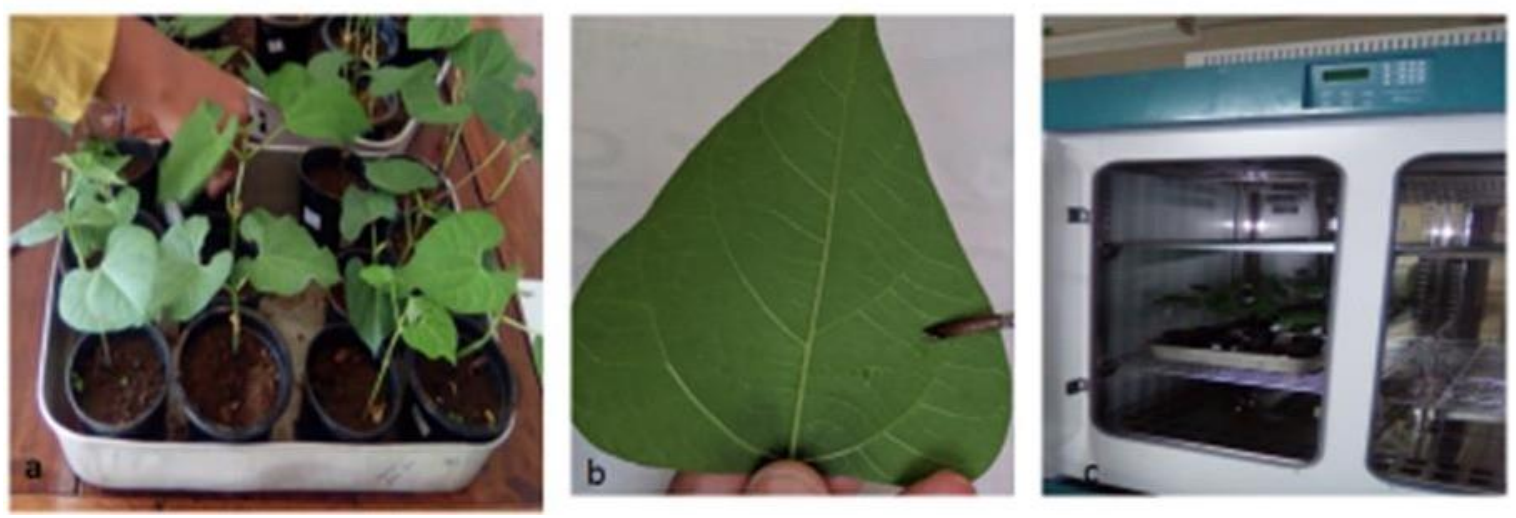

Figure 1 Inoculation procedure: a: plants at appropriate age for inoculation, b: application of rust spore suspension to leaves, $c$ : incubation in moist chamber

\section{DNA Marker Analysis}

The DNA was extracted from young leaves of the parental common beans $\mathrm{P}_{1}$, Kappetipola nil (susceptible) and $\mathrm{P}_{2}$, PI 181996 (resistant), $\mathrm{F}_{1}, \mathrm{~F}_{2}$, and $\mathrm{BC}_{1} \mathrm{~F}_{1}$ plants using the CTAB DNA extraction protocol (Souza et al., 2014). For molecular marker validation, the DNA markers especially linked to Ur-11 resistant genes were used. We assessed the RAPD marker OPAC 20, and SCAR marker SAE 19 and Ur 11-GT-2 following Souza et al. (2014). Each amplification reaction mixture of $25 \mu$ l contained $30 \mathrm{ng}$ of DNA, $0.1 \mathrm{mM}$ dNTPs, $2.8 \mathrm{mM} \mathrm{MgCl}$, $10 \mathrm{mM} / 50 \mathrm{mM}$ Tris $\mathrm{HCl}$ (pH 8.3), and $0.2 \mathrm{mM}$ of each primer with $1 \mathrm{U}$ Taq polymerase.
Annealing temperatures were adjusted, as shown in Table 2 fordifferent primers. Each amplification in the PCR reaction consisted of an initial denaturation step at $94^{\circ} \mathrm{C}$ for $3 \mathrm{~min}, 34$ cycles at 94 ${ }^{\circ} \mathrm{C}$ for $1 \mathrm{~min}, 58^{\circ} \mathrm{C}$ (relevant annealing temperature) for $1 \mathrm{~min} 30 \mathrm{~s}, 72{ }^{\circ} \mathrm{C}$ for $1 \mathrm{~min} 30 \mathrm{~s}$, and final step $72{ }^{\circ} \mathrm{C}$ for $7 \mathrm{~min}$. The amplified products were analyzed in a $1.5 \%$ agarose gel containing Ethidium Bromide $(0.2 \mathrm{mg} / \mathrm{mL})$ immersed in the TBE buffer (90 nm Tris-borate, 1mM EDTA, pH 8). The DNA bands were visualized under ultraviolet light, and digital images were recorded using an Eagle Eye II imaging system (Viber, South Korea). 
Table 2. Selected DNA markers linked to Ur-11 gene in chromosome 11

\begin{tabular}{|c|c|c|c|}
\hline Marker & Primer sequence & $\begin{array}{l}\text { Distance and } \\
\text { Product size }\end{array}$ & $\operatorname{Tm}^{\circ} \mathrm{C}$ \\
\hline OPAC 20 & ACGGAAGTGC & $\begin{array}{l}0 \mathrm{cM} \text { (Coupling) } \\
490 \mathrm{bp}\end{array}$ & 35 \\
\hline SCAR marke & & & \\
\hline SAE 19 & $\begin{array}{l}\text { F- CAGTCCCTGACAACATAACACC } \\
\text { R-CAGTCCCTAAAGTAGTTTGTCCCTA }\end{array}$ & $\begin{array}{l}1.0 \mathrm{cM} \text { (Repulsion) } \\
890 \mathrm{bp}\end{array}$ & 58 \\
\hline UR11-GT- 2 & $\begin{array}{l}\text { F-CGCACTTAGGAGCACAAA } \\
\text { R-TGGTGGGTCCCATATTTTG }\end{array}$ & $\begin{array}{l}0 \quad \& \quad 5.4 \quad \mathrm{cM} \\
\text { (Coupling) } \\
450 \mathrm{bp}\end{array}$ & 60 \\
\hline
\end{tabular}

\section{RESULTS AND DISCUSSION}

\section{Phenotypic Screening}

Parental lines and their successive progenies $\left(\mathrm{F}_{1}, \mathrm{~F}_{2}\right.$, $\left.\mathrm{BC}_{1} \mathrm{~F}_{1}\right)$ were scored visually for the disease symptoms and characterized on a 1-6 scale (Figure 2). Donor parent 181996 showed resistance and immune reaction to tested prevalent rust races (63$21,23-5,31-1$, and 31-11).
All $F_{1}$ plants showed the same resistance pattern as PI 181996 with all the tested local races of $U$. appendiculatus (Table 3 ).

The selected recommended snap bean variety Kappetipola nil $\left(\mathrm{P}_{1}\right)$, used as the recurrent susceptible parent showed susceptible reaction to all of the four races of the rust pathogen used in this study: 63-21, 23-5, 31-1, and 31-11. Phenotypic segregation for resistance was observed with the $\mathrm{F}_{2}$ and $\mathrm{BC}_{1} \mathrm{~F}_{1}$ populations when inoculated with the above four pathogen races (Table 3 ).
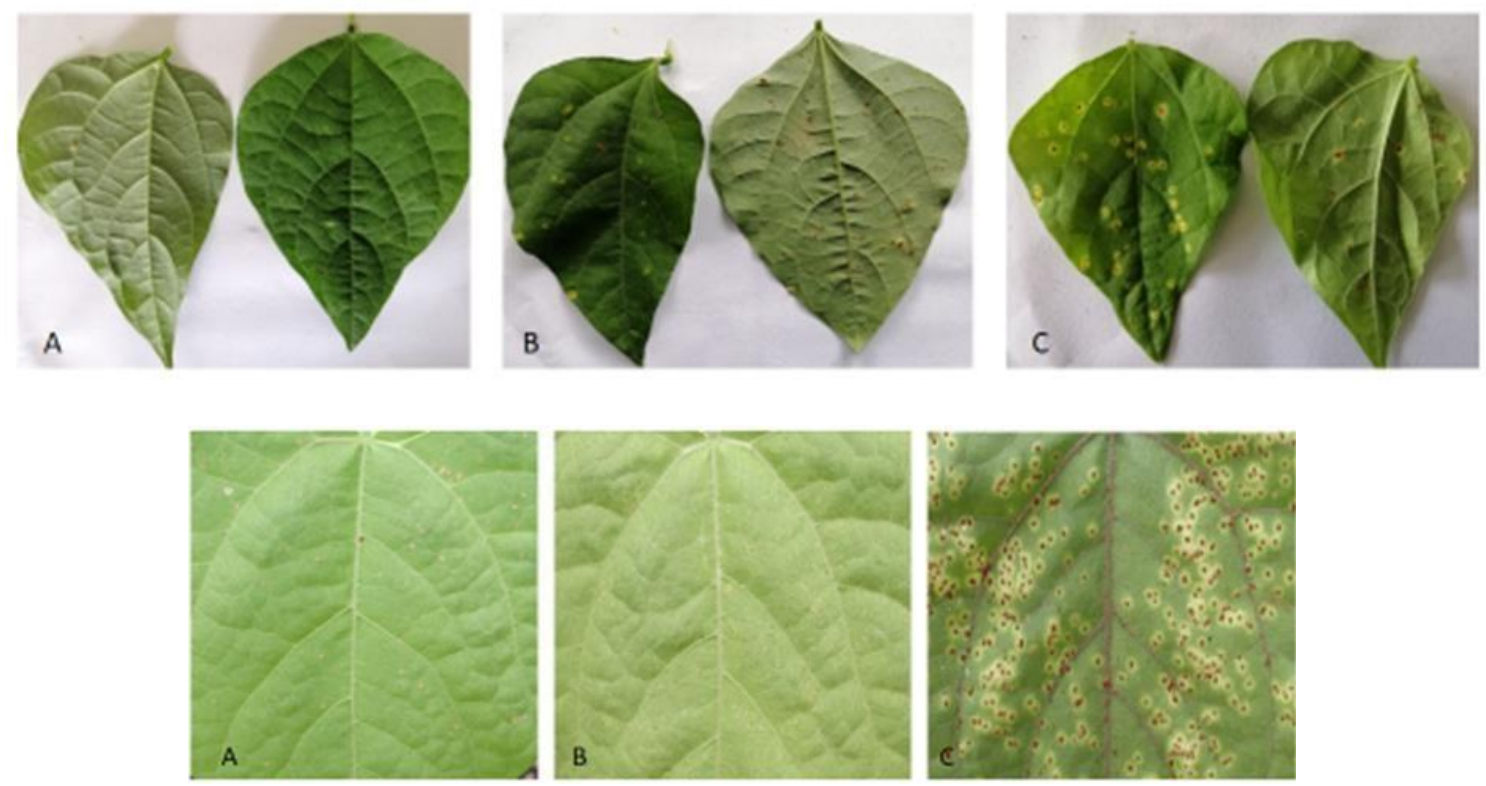

Figure 2. Rust infected bean leaves: A: Resistant or Immune, B: Resistant less than scale 3, C: Susceptible 
Table 3. Inheritance of the Ur-11 gene in the snap bean cross between Kappetipola nil x PI 181996 based on phenotypic screening

\begin{tabular}{|c|c|c|c|c|c|c|c|}
\hline \multirow[t]{2}{*}{ Population } & \multirow{2}{*}{$\begin{array}{l}\text { No of } \\
\text { plants }\end{array}$} & \multicolumn{2}{|c|}{ Observed number } & \multicolumn{2}{|c|}{ Expected number } & \multirow[b]{2}{*}{ tible } & \multirow[t]{2}{*}{ Probability } \\
\hline & & Resistant & Susceptible & Resistant & & & \\
\hline $\begin{array}{l}\mathrm{P}_{1} \\
\text { (Kappetipola } \\
\text { nil) }\end{array}$ & 10 & 0 & 10 & 0 & 10 & & \\
\hline $\begin{array}{l}P_{2} \\
\text { (PI 181996) }\end{array}$ & 10 & 10 & 0 & 10 & 0 & & \\
\hline $\mathrm{F}_{1}$ & 50 & 50 & 0 & 50 & 0 & & \\
\hline $\mathrm{F}_{2}$ & 280 & 215 & 65 & 210 & 70 & 0.4761 & 0.4901 \\
\hline $\mathrm{BC}_{1} \mathrm{~F}_{1}$ & 76 & 42 & 34 & 38 & 38 & 0.8421 & 0.3587 \\
\hline
\end{tabular}

In the $F_{2}$ population, 215 individuals showed resistance, and 65 individuals showed a susceptible reaction with all four rust races (Table 4). Inheritance of resistance in the $F_{2}$ population was close to the 3:1 ratio, following Mendelian genetics with introgression of the resistant gene, suggesting a major single dominant gene action. The observed $\chi^{2}$ values were comparable with expected values. All $\mathrm{F}_{1}$ plants were resistant, responded with immune, and resistant reactions (infection degrees 1 and 2) when inoculated with the four local races (Table 4).
Some of the $\mathrm{F}_{2}$ resistant plants showed an immune to a resistant reaction (infection degree1, 2), while some susceptible plants showed a 5 to 6 infection range of susceptible reactions (Table 4). As shown in Table 4, the donor resistant parent PI 181996 with the $U r-11$ rust resistance gene is an excellent source to develop rust resistance in the local bean varieties in Sri Lanka. In the $\mathrm{BC}_{1} \mathrm{~F}_{1}$ population, 42 and 34 plants showed resistant and susceptible reactions, respectively, with all four rust races revealing confirmation of gene action in the $\mathrm{F}_{2}$ population.

Table 4. Infection degrees of selected common bean lines to local rust races

\begin{tabular}{|c|c|c|c|c|c|c|c|c|c|c|c|c|}
\hline $\begin{array}{l}\text { Rust } \\
\text { race }\end{array}$ & $\mathbf{P}_{1}$ & $\mathbf{P}_{2}$ & $\begin{array}{c}\mathbf{1} \\
\underset{\vec{x}}{\vec{x}}\end{array}$ & 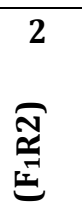 & 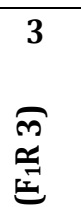 & 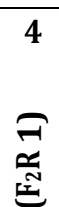 & 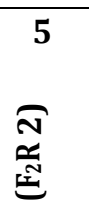 & $\begin{array}{r}6 \\
\underset{\tilde{N}}{\tilde{c}}\end{array}$ & 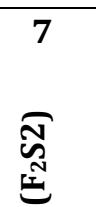 & $\begin{array}{l}\mathrm{BC}_{1} \mathrm{~F}_{1} \\
\text { R 1 }\end{array}$ & $\begin{array}{l}\mathrm{BC}_{1} \mathrm{~F}_{1} \\
\mathrm{S1}\end{array}$ & $\begin{array}{l}\mathrm{BC}_{1} \mathrm{~F}_{1} \\
\mathrm{~S} 2\end{array}$ \\
\hline $63-21$ & 6,5 & 1,2 & 1 & 1,2 & 1,2 & 1 & 1 & 6,5 & 5,6 & 1,2 & 4,5 & 5,6 \\
\hline $23-5$ & 6 & 1 & 1,2 & 1 & 1,2 & 1 & 1,2 & 5,4 & 6 & 1,2 & 5 & 5,6 \\
\hline $31-11$ & 6,5 & 1,2 & 1 & 1 & 1 & 1 & 1 & 6,5 & 5,6 & 1 & 5 & 6 \\
\hline $31-1$ & 5,4 & 1 & 1 & 1 & 1 & 1 & 1 & 5 & 5,6 & 1 & 6,5 & 6 \\
\hline
\end{tabular}

$\mathrm{P}_{1}$ Resistantrecurrent parent, $\mathrm{P}_{2}$ Donor parent, $1,2,3$ selected $\mathrm{F}_{1}$ plants-resistant 4 ,

5 , selected resistant $F_{2}$ plants, 6,7 selected $F_{2}$ susceptible plant

$\mathrm{BC}_{1} \mathrm{~F}_{1} \mathrm{R}$ back cross resistant plants, $\mathrm{BC}_{1} \mathrm{~F}_{1} \mathrm{~S}$ back crossed susceptible plants 
We observed 3:1 segregation ratio of resistant to susceptible in the $\mathrm{F}_{2}$ population and a close to $1: 1$ ratio with the $\mathrm{BC}_{1} \mathrm{~F}_{1}$ population. Therefore, the results suggest a monogenic, dominant behavior of the resistant gene obtained from PI 181996 in the segregating populations, as previously reported (Souza et al., 2014). The resistant $\mathrm{F}_{2}$ and $\mathrm{BC}_{1} \mathrm{~F}_{1}$ individual plants with superior characteristics and yield parameters were selected for the next breeding cycle.

\section{Molecular Screening}

We used molecular markers to confirm the presence of Ur-11 gene in phenotypically identified plants with resistance to $U$. appendiculatus. The RAPD marker OPAC 20 is polymorphic in the susceptible parent Kappetipola nil and resistant parent PI 181996 (Figure 3A).

A

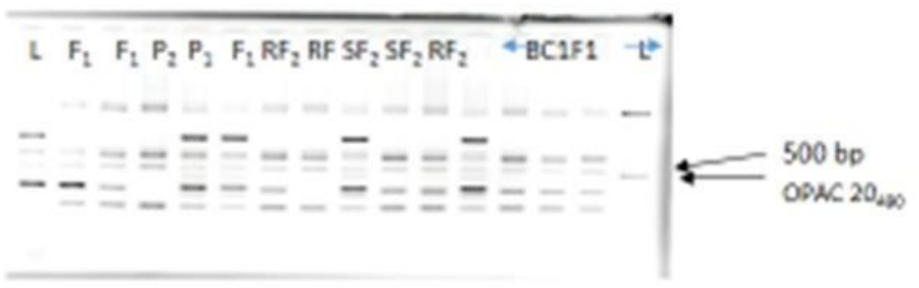

B

1. $\mathrm{P}_{2} \quad \mathrm{P}_{2} \quad \mathrm{~F}_{2} \quad \mathrm{SF}_{2} \quad \mathrm{BF}_{2} \quad \mathrm{BF}_{2} \quad \mathrm{SF}_{2} \quad \mathrm{SF}_{2} \quad \mathrm{SE} \quad \mathrm{L}$.

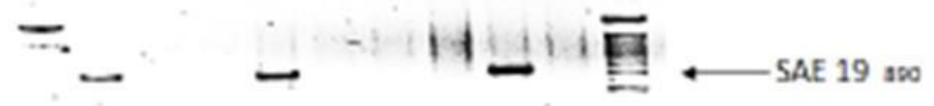

$\begin{array}{lllllllllllllll}C & L & R F_{2} & R F_{1} & P_{2} & P_{1} & R F_{2} & R F_{2} & S F_{2} & S F_{2} & S F_{2}\end{array}$
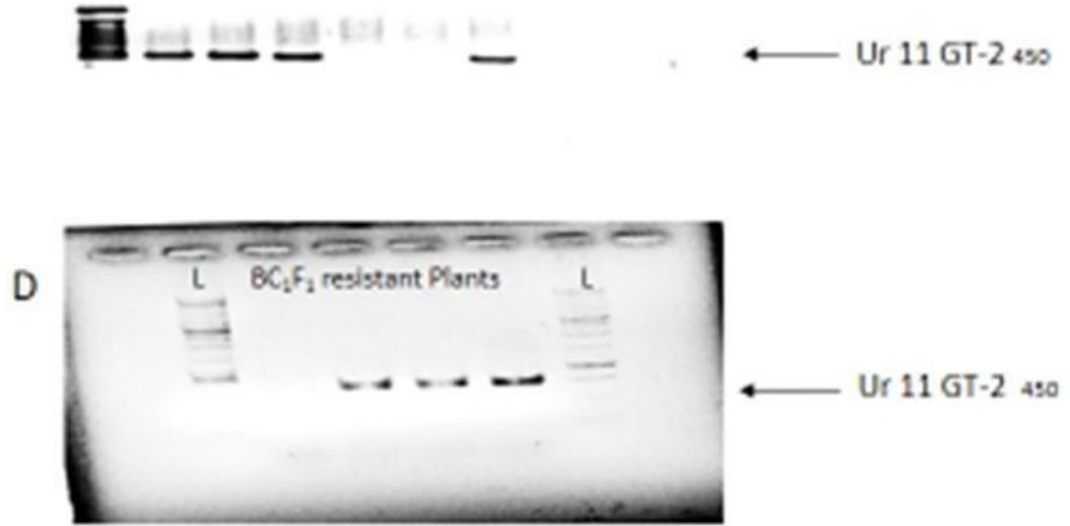

Figure 3. Electrophoretic analysis on $1.2 \%$ agarose gel of amplification DNA products obtained with the RAPD marker OPAC 20 (A), repulsion SCAR marker SAE19 (B), Coupling SCAR marker UR GT 2 (C, D) linked to gene Ur11. Lanes are as follows: L lambda DNA cut with EcoRI, BamHI and HindIII (size marker), P1 parent (susceptible), P 2 donor parent (Resistant), F1 plants, RF2 resistant F2 plants, SF2 susceptible F2 plants, $\mathrm{BC1F1}$ resistant $\mathrm{BC1F1}$ plants.

The same marker has also been previously used successfully in rust resistance breeding (Miklas et al., 2002). Interestingly, in the current study, the RAPD marker OPAC 20490 was present in $95 \%$ of the resistant segregating lines suggesting a higher percentage of selection efficiency. Previous studies suggested that the OPAC $20_{490}$ marker is linked closely to the Ur-11 gene (Souza et al., 2014).
Therefore, the current results confirm that the Ur 11 gene has introgressed in the resistant lines of subsequent generation from the variety PI 181996 (Figure 3 B). As such, this RAPD marker associated with the gene $(U r-11)$ present in the rust-resistant bean lines is suitable for the local resistant breeding program. 
The DNA repulsion SCAR marker SAE 19 amplified the susceptible parent $\left(\mathrm{P}_{1}\right)$, susceptible $\mathrm{F}_{2}$ individuals, and $\mathrm{BC}_{1} \mathrm{~F}_{1}$ individuals (Figure $3 \mathrm{C}$ ). The repulsion SCAR marker SAE 19 did not produce any bands in the resistant donor parent. The PCR product of around $890 \mathrm{bp}$ present in some resistant $\mathrm{F}_{2}$, and $\mathrm{BC}_{1} \mathrm{~F}_{1}$ progenies may be due to interference with recombinant progenies as experienced by other researchers too (Souza et al., 2014; HurtadoGonzales et al., 2017). This particular PCR product was not present any of the susceptible plants in the recurrent parent $\left(\mathrm{P}_{1}\right), \mathrm{F}_{2}$, and $\mathrm{BC}_{1} \mathrm{~F}_{1}$ generations. Souza and colleagues (Souza et al., 2014) suggested the use of SAE 19 repulsion marker in the identification and differentiation of susceptible lines.

The specific SCAR markerUR11-GT-2 was present in PI 181996, but it was absent in Kappetipola nil (Figure 3C). Molecular analysis of all the populations showed that SCAR marker UR11-GT-2 polymorphic between resistant and susceptible plants (3 C, D). Validated RAPD and SCAR markers showed higher than $95 \%$ compatibility with rustresistant and susceptible plants characterized by the standard phenotyping method. A few (two $F_{1}$, Five $\mathrm{F}_{2}$ and to three $\mathrm{BC}_{1} \mathrm{~F}_{1}$ ) phenotypically resistant plants did not have clear bands for the presence of the relevant gene with the SCAR marker. This observation could be due to a recombination event between the SCAR marker and the $U r-11$ gene. The majority of the rust-resistant individuals from the $\mathrm{F}_{2}$ population and $\mathrm{BC}_{1} \mathrm{~F}_{1}$ population produced expected PCR products for the SCAR marker UR1 UR11-GT-2 (Figure 3 C, D).

Overall, the results suggest that the rust resistance governed by the $U r-11$ gene present in PI 181996 has been incorporated into the resistant lines of $\mathrm{F}_{2}$ and $\mathrm{BC}_{1} \mathrm{~F}_{1}$ of the Kappetipola nil x PI 181996 cross. When the same plants were assessed using both the phenotypic and the genetic markers, data agreed with more than $95 \%$ accuracy. Coupling markers OPAC 20 and Ur-11-GT-2 showed the same resistant and susceptible ratio with $\mathrm{F}_{2}$ (3:1) and BC1F1 (1:1) as observed during the phenotypic screening of the same individuals. Current results suggest that the SCAR marker UR 11-GT-2 could be used to confirm the introgression of the $U r-11$ gene in successive generations (Fig 3D). Further, the coupling and repulsion markers may use separately or together to improve selection efficiency with $U r$ -11 gene.

The SCAR marker UR 11-GT-2 has previously been used to accelerate the identification of the Ur- 11 gene in the donor parent, PI 181996, in previous studies. New local snap bean lines enriched with the resistant allele (Ur-11) were obtained with backcrossed progenies and were successfully identified at an early stage using conventional and molecular marker tools. Yield improvement and disease resistance are the main objectives of bean breeding. Therefore, identification of the molecular markers for rust resistance will be helpful in further gene pyramiding strategies. As previous authors suggested, the development and application of SNP markers may increase reproducibility and efficiency (Hurtado- Gonzales et al., 2017) in resistant breeding.

\section{CONCLUSIONS}

The current study confirmed the gene Ur-11 in cultivar PI 181996 to be an excellent source of resistance for rust-resistance breeding in Sri Lanka. The $U r-11$ is a dominant gene, and introgression of this gene to local variety Kappetipola nil can be confirmed using both phenotypic screening methods using the races of rust pathogen and with the developed DNA markers. RAPD marker OPAC 20 with more than 95\% positive results link with $U r-11$ gene introgression. The local varietal crosses with the Middle American common bean accession PI 181996 produced reliable results that agree with the phenotypic data in $95 \%$ and $100 \%$ with the SCAR marker UR 11-GT-2 (F-CGC ACT TAG GAG CAC AAA, R-TGG TGG GTC CCATATTTTG) and SCAR marker SAE19 (F-CAGTCCCTGACAACATAACACC, R-CAGTCCCTAAAGTAG TTT GTCCCTA) respectively. Therefore, as more specific markers, SCAR marker UR11-GT-2 and SAE 19 marker can be used for marker-assisted selection in snap bean breeding for the introgression of the $U r-11$ gene.

The current study confirmed the gene $U r-11$ in cultivar PI 181996 to be an excellent source of resistance for rust-resistance breeding in Sri Lanka. The Ur-11 is a dominant gene, and introgression of this gene to local variety Kappetipola nil can be confirmed using both phenotypic screening methods using the races of rust pathogen and with the developed DNA markers. RAPD marker OPAC 20 with more than 95\% positive results link with Ur-11 gene introgression. The local varietal crosses with the Middle American common bean accession PI 181996 produced reliable results that agree with the phenotypic data in $95 \%$ and $100 \%$ with the SCAR marker UR 11-GT-2 (F-CGC ACT TAG GAG CAC AAA, R-TGG TGG GTC CCATATTTTG) and SCAR marker SAE19 (F-CAGTCCCTGACAACATAACACC, RCAGTCCCTAAAGTAG TTT GTCCCTA) respectively. Therefore, as more specific markers, SCAR marker UR 11-GT-2 and SAE 19 marker can be used for marker-assisted selection in snap bean breeding for the introgression of the $U r-11$ gene. 


\section{ACKNOWLEDGEMENT}

This research was funded by the Department of Agriculture, Sri Lanka, and Sri Lanka Council for Agricultural Research Policy. This research was made possible by the Department of Plant Soil and Microbial Sciences, Michigan State University, East Lansing, Michigan, USA. We wish to thank the Common bean research project of the Soybean Genomics and Improvement Laboratory, Beltsville Agricultural Research Center, ARS-USDA, Beltsville, Maryland, USA for providing the common bean differential cultivars and technical assistance.

\section{REFERENCES}

Acevedo, M., Steadman, J.R., Eskridge, K.M. (2008). Monitoring changing virulence patterns of Uromyces appendiculatus with its wild, weedy and domesticated hosts (Phaseolus spp) at a center of diversity. Annual report of the Bean Improvement Cooperative, 51,22-23.

Alleyne, A.T., Steadman, J.R., Eskridge, K.M. (2008). Monitoring changing virulence patterns of Uromyces appendiculatus in the resistant pinto bean cultivar Olanthe by rep-PCR. European Journal of Plant Pathology, 122, 315-319.

Araya, C.M., Alleyne, A.T., Steadman, J.R., Eskridge, K.M., and Coyne, D.P. (2004). Phenotypic and genotypic characterization of Uromyces appendiculatus from Phaseolus vulgaris in the Americas. Plant Disease, 88, 830-836.

Ariyarathna, H., \& Nuwan, E. (2001). A simple method to screen bean seedlings against bean rust. Annals of the Sri Lankan Department of Agriculture, 3, 1-7.

Broughton, W.J., Hernandez, G., Blair, M., Beebe, S., Gepts, P., \& Vanderleyden, J. (2003). Beans (Phaseolus spp.)-model food legumes. Plant Soil, 252, 55-128.

Hangen L., Benink, M.R. (2003). Consumption of black beans and navy beans (Phaseolus vulgaris) reduced azoxymethane-induced colon cancer in rats. Nutrition and Cancer, 44, 60-65.

Hurtado-Gonzales, O.P., Valentini, G., Gilio, .A.S., Martins, A.M., Song, Q., \& Pastor-Corrales, M.A. (2017). Fine mapping of Ur-3, a historically important rust resistance locus in common bean. $G 3,7,557-569$.
Kakolongo A.M. (2018). Challenges and opportunities for improvement Legumes, Food Crop Production by small holder farmers in South Africa. Elsevier, Academic Press, Chapter 10, 173-203.

Kelly J.D., Gepts, P., Miklas, P.N., Coyne, D.P. (2003). Tagging and mapping of genes and QTL and molecular marker assisted selection for traits of economic importance in bean and cowpea. Field Crops Research. 82, 135-154.

Liebenberg, M.M., Liebenberg A.J., \& Pretorius, Z.A., (2003).Improvement of the rust resistance of dry beans in South Africa. Annual Report International Bean Improvement Cooperative meeting. 46, 185-186.

Miklas, P.N., Pastor Corrales, M.A., Jung, G., Coyne, D.P., Kelly, J.D., Mc Clean, P.E., and Gepts, P. (2002). Comprehensive linkage map of bean rust resistance genes. Annual Report International Bean Improvement Cooperative meeting. 45, 125-129.

Miklas, P.N., Kelly, J.D, Beebe, S.E., Blair, M.W. (2006). Common bean breeding for resistance against biotic and abiotic stresses from classical to MAS breeding. Euphytica. 147, 105-131.

Pastor Corrales, M.A. (2001). The reaction of 19 bean rust differential cultivars to 94 races of Uromyces appendiculatus and the implication for the development of rust resistance cultivars. Annual Report International Bean Improvement Cooperative meeting. 44, 103104.

Souza, T.L.P.O., Ragagnin, V.A., Sanglard, D.A., Moreira, M.A. \& Barros, E.G. (2007). Identification of races of selected isolates of Uromyces appendiculatus from Minas Gerais (Brazil) based on the new international classification system. Fitopatologia Brasileira, 32,104-109.

Souza, T.L. P.O., Ragagnin, V., Dessaune, S., Alves, M.M. (2014). DNA marker assisted selection to pyramid rust resistance genes in carioca seeded common bean lines. Euphytica 199: 303-316 [online] [Accessed on 25. 02. 2010]. http://WWW.researchgate.net/publication/271 738621 
Stavely, J.R. (2000). Pyramiding rust and viral resistance genes using traditional and marker techniques in common bean. Annual Report International Bean Improvement Cooperative meeting. 43, 1-4.
Steadman, J.R., Pastor-Corrales, M.A., \& Beaver, J.S. (2002). An overview of the 3rd Bean Rust and 2nd Bean Common Bacterial Blight International Workshops, March 4-8, 2002, Pietermaritzburg, South Africa. Annual Report International Bean Improvement Cooperative meeting. 45, 120-12 